\title{
Current Methodologies for Membrane Permeability Assessment
}

\author{
Beom Soo Shin', Yu Seok Youn ${ }^{2}$, Seong Hoon Jeong², Eun-Seok Park ${ }^{3}$, \\ Mann Hyung Lee ${ }^{1}$ and Sun Dong Yoo $^{3 \dagger}$ \\ ${ }^{1}$ College of Pharmacy, Catholic University of Daegu, 330 Geumrak 1-ri, Hayang Eup, \\ Gyeongsan si, Gyeongbuk, 712-702, Republic of Korea \\ ${ }^{2}$ College of Pharmacy, Pusan National University, Jangjeon-dong, Geumjeong-gu, Busan 609-735, Republic of Korea \\ ${ }^{3}$ College of Pharmacy, Sungkyunkwan University, 300 Chonchon-dong, Jangan-gu, Suwon City 440-746, Republic of Korea \\ (Received September 13, $2010 \cdot$ Revised October 4, 2010 • Accepted October 5, 2010)
}

\begin{abstract}
Orally administrated drugs permeate the biological membrane by various transport mechanisms. The oral absorption potential is closely related to the physicochemical properties of the drug and interaction with the physiological factors surrounding the site of absorption. Assessment of the drug membrane permeability is an integral part of the early stage drug developmental process. Appropriate selection of the permeability screening method at the right stage of drug development process is important in achieving successful developmental outcomes. This review aims at introducing currently available in vitro and in vivo screening methods for the membrane permeability assessment.
\end{abstract}

Key words - Membrane permeability, absorption, Caco-2, PAMPA, intestinal perfusion.

The drug discovery is an expensive and time consuming process with high-risk of failure (DiMasi et al., 1994; Kaitin and Healy, 2000; Kaitin et al., 2000). To become the successful drug candidate, good biological properties such as potency, selectivity, efficacy and oral bioavailability are required. Traditionally, drug discovery groups have focused primarily on the pharmacological aspects including potency and efficacy, without much attention given to the importance of the pharmacokinetic characterization in the early stage of drug development. The proportion of failure of investigational new drug (IND) applications has been estimated approximately $87 \%$ in Phase I, 60\% in Phase II, and 20\% in Phase III clinical studies, and only one compound is released to the market out of 9,00010,000 newly synthesized compound (Kennedy, 1997). The primary reason for this high failure rate over the past 20 years was in part due to the pharmacokinetic inadequacy including low aqueous solubility, inadequate intestinal permeability, low chemical stability, intestinal or hepatic metabolism, and systemic clearance, although more attention is being given to the pharmacokinetic characterization in recent years and the failure rate is decreasing (Ganta et al., 2008). Owing to the combinatorial chemistry and automated high throughput screening, it is common to screen 100,000 compounds in a 1- to 6-month period (Broach and Thorner, 1996; Silverman et al., 1998), and

Corresponding Author :

Tel : +82-31-290-7717, E-mail : sdyoo@skku.ac.kr

DOI : $10.4333 /$ KPS.2010.40.S.019 this makes it possible to generate thousands of therapeutically active compounds in a short time period. However, the number of drugs released on the market has not been increased. Thus, in recent drug discovery, evaluation of the pharmacokinetic properties is being performed in the early stage of drug discovery. It provides useful information to design optimal pharmaceutical preparations without wasting valuable resource and time (Ganta et al., 2008).

Among various innovative drug delivery systems, the most preferred route of administration is still the oral route due to the ease of administration and high patient compliance. Oral bioavailability is the most crucial factor for molecules that are intended for oral administration. Oral bioavailability of a molecule is influenced by multiple factors, including solubility, permeability and intestinal and liver metabolism. There are various techniques used to assess the gastrointestinal absorption potential of new drug candidates. This article will focus on the permeability evaluation methods that are currently utilized in the drug development process.

\section{Drug transfer through physiological membrane}

The human small intestine is divided by duodenum, jejunum, and ileum and the approximate total length is 2-6 m. The major role of the small intestine is the barrier function to ingested foreign substances and absorption of nutrients and drugs. Approximately $90 \%$ of total absorption occurs in the small intestine (Balimene et al., 2000). The enterocytes, the major cells of the small intestine, act as the intestinal barrier. 


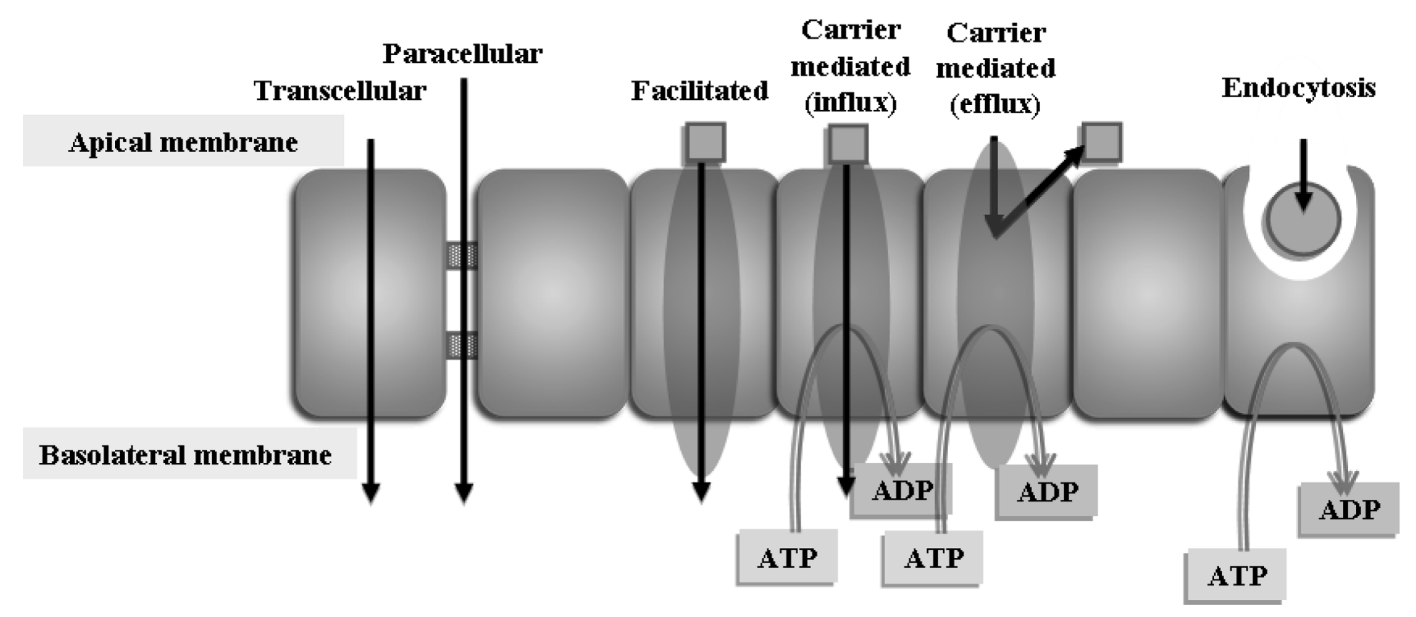

Figure 1. Routes of drug permeation in the gastrointestinal tract.

Other than enterocytes, the small intestine is consisted of various cells such as globlet cells, endrocrine cells, paneth cells, $\mathrm{M}$ cells, tuft and cup cells (Carr and Toner, 1984; Madara and Trier, 1987). The structure of the cellular membrane is composed of the phospholipid bilayer, with each enterocyte separated by negatively charged tight junction. The majority of lipophilic drugs are absorbed by passive diffusion through the cell membrane, which is called the transcellular transport (Camenisch et al., 1996). In contrast, the hydrophilic and small (MW <200) compound passes through the water-filled tight junction formed by fusion of adjacent cells (paracellular transport) (Conradi et al., 1996). If the drug is a substrate for intestinal transporters, its movement is significantly affected by these transporters. In active transport, drug molecules are transported against the concentration gradient by consuming energy (Hunter et al., 1993a). However, in facilitated transport, drug molecules are transported to the concentration gradient direction without consuming energy. Among various intestinal transports, P-glycoprotein (P-gp) is the most typical efflux transporter located in the apical side of membrane. (Thiebaud et al., 1987; Croop et al., 1989; Burton et al., 1993; Benet et al., 1996; Hidalgo and Li, 1996; Tsuji and Tamai, 1996; Sandstrom et al., 1998). High molecular weight compounds such as peptides and proteins tend to be transported by endocytosis (Hunter et al., 1993b). The various drug transport processes described above are summarized in Figure 1.

\section{Physicochemical drug properties affecting intestinal permeability}

The major physicochemical properties of a chemical that influence the passive intestinal permeability are the lipophilicity, molecular weight, hydrogen bonding, $\mathrm{pKa}$, and solubility. A number of review articles have reported the relationship between the molecular properties and the intestinal permeability (Kramer, 1991; Clark and Pickett, 2000; Stenberg et al., 2000; Van de Waterbeemd, 2000; Clark, 2001; Van de Waterbeemd et al., 2001). The most widely used model describing the relationship between the molecular properties and the intestinal permeability was introduced by Lipinski et al. (1997) which is called the "rule of 5 model". This model states that a poor absorption or permeation is likely to occur when the calculated 1) hydrogen bond (H-bond) donors are more than five, 2) H-bond acceptors are more than ten, 3) the MW is over 500 , and 4) $\log \mathrm{P}$ is over five. When the physicochemical properties of a chemical meet more than two of these criteria, poor membrane permeability is to be anticipated. This model is simple and easy to interpret and fast to compute. However, this model is often of a limited scope as it does not take into account the physiological factors including the membrane transporters. Thus, substrates for the biological transporters become exception to the rule of five. The factor of the rule of five can be predicted by the computational method and these factors will be discussed below.

\section{Lipophilicity}

It has long been recognized that the lipophilicity is an important factor determining the membrane permeability (Leo et al., 1971; Hansch and Dunn, 1972; Hansch and Clayton, 1973). An adequate lipophilicity is essential for cell membrane permeation as it provides affinity between a drug molecule and the phospholipid membrane structure (Kramer, 1999). In the Fick's first law, the membrane permeability is proportionally increased as the membrane-water partition coefficient $(\mathrm{K})$ increased. The cell membrane is composed of phospholipid bilayers that are both hydrophilic and lipophilic in nature. Thus, the relationship between lipophilicity and permeability is 
nonlinear from low to high lipophilicity. These nonlinearities are due to a limited diffusion of less lipophilic molecules and an entrapping at the lipophilic portion of the phospholipid bilayer of high lipophilic molecule, preventing movement through the aqueous portion of the bilayer membrane (Hansch and Clayton, 1973; Martin, 1981; Gobas et al., 1988; Kararli, 1989; Dearden, 1990; Wils et al., 1994). Lipophilicity is conventionally expressed as the octanol/water partition coefficient $(\log \mathrm{P})$ or the distribution coefficient $(\log \mathrm{D})$ which is a $\mathrm{pH}$ dependent term of ionizable drugs. The $\log \mathrm{P}$ and $\log \mathrm{D}$ are determined by the shake flask method. In this method, the sample is dissolved in a flask containing $n$-octanol-water biphasic system and the flask is shaken until equilibrium is achieved between phases. Then, the phase is separated and the sample concentration and the $\mathrm{pH}$ of aqueous phase are measured. Finally, $\log \mathrm{P}$ and $\log \mathrm{D}$ are calculated by the following equations (Comer, 2003):

$$
\begin{aligned}
& \mathrm{P}=\frac{[\text { solute }]_{\mathrm{octanol}}}{[\text { solute }]_{\text {watar }}} \\
& \mathrm{D}=\frac{[\text { unionized }+ \text { ionized solute }]_{\mathrm{octanol}}}{[\text { unionized }+ \text { ionized solute }]_{\mathrm{water}}}
\end{aligned}
$$

The $\log \mathrm{P}$ and $\log \mathrm{D}$ can also be determined by computational approaches. These approaches allow the calculation of the $\log \mathrm{P}$ values with incorporation data such as atomic contribution or molecular fragment or molecular properties including molecular lipophilicity potential (MLP) (Testa et al., 1996), molar volume, and hydrogen bonding (Ganta et al., 2008). These computational approaches are summarized in Table I
(Ganta et al., 2008).

\section{Hydrogen bonding (H-bonding)}

Hydrogen bonding capacity is a major component of the lipophilicity along with the molecular size (Van de Waterbeem and Testa, 1987; Tayar et al., 1992). Various studies have reported a correlation between the hydrogen bonding capacity and the membrane permeability (Van de Waterbeemd et al., 1996; Dearden and Ghafourian, 1999; Raevsky and Schaper, 1998; Raevsky et al., 2000). Hydrogen bonding can be measured experimentally from the difference between octanol/ water and alkane/water partitioning $(\Delta \log p)$. However, the measurement of $\log \mathrm{p}$ is a tedious experiment since octanol is miscible with alkane and the compound distribution of these two solvents cannot be measured simultaneously. As a more convenient measurement, the hydrogen bonding capacity may be calculated by counting the number of hydrogen bond donor atoms (hydrogen) attached to oxygen and nitrogen and hydrogen bond acceptor atoms (oxygen and nitrogen) (Lipinski et al., 1997). The hydrogen bond capacity may also be calculated by using the polar surface area (PSA) which measures the PSA of all N- and O-atoms (Van de Waterbeemd and Kansy., 1992). The relationship between the oral absorption and the polar surface area can be described by the following equation:

$$
A \%=100 /\left[1+\left(\frac{P S A}{P S A_{50}}\right)^{\gamma}\right]
$$

where $\mathrm{A} \%$ represents the percentage of orally absorbed drug and $\mathrm{PAS}_{50}$ represents the PSA at $50 \%$ absorption level.

Commonly, poorly absorbed compounds have high polar

\begin{tabular}{|c|c|c|}
\hline Name & Software Package/Vendor & Web site \\
\hline PrologP and Prolog P & PALLAS/CompuDrug Chemistry Ltd. & http://www.compudrug.com/ \\
\hline $\mathrm{ACD} / \log \mathrm{P}$ and $\log \mathrm{D}$ & Verson 3.0/Advanced Chemistry Development Inc. & http://www.acdlabs.com/home/ \\
\hline CLOGP & $\begin{array}{l}\text { Pcmodels/Daylight CIS, CLOGP/Biobyte } \\
\text { OSIRIS Property Explorer/ Thomas Sander }\end{array}$ & $\begin{array}{l}\text { http://www.daylight.com/ http://www.biobyte.com/ } \\
\text { http://www.organic-chemistry.org/prog/peo/ }\end{array}$ \\
\hline $\mathrm{HINT} / \log \mathrm{P}$ & Edusoft & http://www.edusoft-lc.com/ \\
\hline KLOGP & Multicase Inc. & http://www.multicase.com/ \\
\hline LOGKOW & Syracuse Research Corp. & http://www.syrres.com/ \\
\hline SCILOGP & SCILOGP/Scivision & http://www.scivision.com/ \\
\hline TLOGP & TLOGP 1.0/Upstream Solutions & http://www.upstream.ch \\
\hline XLOGP & $\begin{array}{l}\text { XLOGP V 2.0/Insitute of Physical Chemistry, Peking } \\
\text { University }\end{array}$ & $\begin{array}{l}\text { http://www.ics.uci.edu/ dock/manuals/xlogp2.1/ } \\
\text { usage.html\#subject_1 }\end{array}$ \\
\hline ALOGPS & $\begin{array}{l}\text { ALOGPS } 2.1 \text { /Virtual Computational Chemistry } \\
\text { Laboratory }\end{array}$ & http://www.vcclab.org/ \\
\hline
\end{tabular}
surface areas $\left(>140 \AA^{2}\right)$ while a complete oral absorption may

Table I. Computer Software Use in the Calculation of $\log P$ 
be anticipated when the polar surface area is less than $60 \AA^{2}$ (Kelder et al., 1997). Recently, a more accurate method for measuring the polar surface area has been introduced based on quantum mechanism and Hybot (Raevsky et al., 1992). In case the intestinal absorption is affected by active transporters and the gut wall metabolism, however, the relationship between the oral absorption and the polar surface area may be broken.

\section{Molecular size}

Molecular size is the component of lipophilicity and diffusion coefficient $(\log \mathrm{D})$ in physiological membrane permeation (Ganta et al., 2008). The transcellular diffusion in the physiological membrane is strongly affected by the molecular size of compound. According to the Lipinski's rule of 5 model, the upper limit of the molecular weight for oral absorption is 500 Da (Lipinski et al., 1997). The most commonly used descriptor for molecular size is the molecular weight. However, this may not be sufficient since the molecular weight contains no three-dimensional information.

\section{In vitro Intestinal Permeability Test}

\section{Parallel artificial membrane permeability assay (PAMPA)}

PAMPA was initially suggested by Mueller et al (1962). They reported that a small amount of phospholipids $(2 \% \mathrm{w} / \mathrm{v}$ alkane solution) placed over a $0.5 \mathrm{~mm}$ small hole in a thin (10$20 \mu \mathrm{m}$ ) sheet of Teflon or polyethylene made a thin film at the center of hole. Such membrane has been shown to be a useful predictor of human drug absorption. However, this lipid membrane has weaknesses as it is fragile and hard to prepare. After this initial finding, various efforts have been made to overcome drawbacks of the artificial membrane permeability assay (Thompson et al., 1982; Cools and Janssen, 1983; Camenisch et al., 1998; Kansy et al., 2001; Avdeef, 2001a; Avdeef et al., 2001b; Faller and Wohnsland, 2001). Recently, PAMPA became a popular industry tool for high throughput permeability screening in early drug discovery due to its high efficacy, reproducibility, and low cost (Lipinski, 2002). PAMPA is run on a 96 microtiter well plate consisting of top and bottom parts. The top part contains a series of filter. One half of the top part is treated with a dispersed phospholipid on an organic solvent, which supposedly acts as the cell membrane and the other part is wet with methanol/buffer. The bottom part which matches with the well on top part is filled with buffer. The various PAMPA membrane compositions are summarized in Table II (Avdeef, 2003). The extent of drug permeation is determined by measuring the permeation rate of the test compound from the top to the bottom part. The membrane permeability of PAMPA is highly correlated with that of the Caco2 system for passively diffused drugs (Camenisch et al., 1997). A good correlation is also found between PAMPA and the human absorption for selected passively transported compounds (Lipinski et al., 1997). Thus, PAMPA is highlighted as an alternative method to cell culture system for predicting passive permeability (Kansy et al., 1998). The limitation of this system is the lack of permeability prediction for the compound that is transported by paracellular pores and carrier proteins. Thus, PAMPA should be used with caution for human oral absorption screening, especially for the carrier-mediated drugs.

\section{Immobilized artificial membrane (IAM) chromato- graphic assay}

The IAM chromatographic assay utilizes the solute interaction with amphiphilic phospholipids covalently bonded to aminopropyl silica particles (Pidgeon et al., 1995; Ong et al., 1996; Taillardat et al., 2003; Yang et al., 1996; Caldwell et al., 1998; Bertschinger et al., 2003). The amphiphilic phospho-

Table II. Membrane Compositions of Various PAMPA Models

\begin{tabular}{|c|c|c|}
\hline Model & Lipid Composition & References \\
\hline $\begin{array}{l}\text { Egg Lecithin PAMPA Model } \\
\text { (Roche Model) }\end{array}$ & $10 \% \mathrm{wt} / \mathrm{vol}$ dodecane solution of egg lecithin & Kansy et al., 1998 and 2001 \\
\hline $\begin{array}{l}\text { Hexadecane PAMPA Model } \\
\text { (Novartis Model) }\end{array}$ & Hexadecane without phospholipid & $\begin{array}{l}\text { Faller and Wohnsland, 2001; } \\
\text { Wohnsland and Faller, } 2001\end{array}$ \\
\hline $\begin{array}{l}\text { Brush-Border Lipid Membrane (BBLM) } \\
\text { PAMPA Model (Chugai Model) }\end{array}$ & $\begin{array}{l}3 \% \mathrm{wt} / \mathrm{vol} \text { lipid solution in } 1,7 \text {-octadiene (lipid consisting } \\
\text { of } 33 \% \mathrm{wt} / \mathrm{wt} \text { cholesterol, } 27 \% \mathrm{PC}, 27 \% \mathrm{PE}, 7 \% \mathrm{PS}, 7 \% \mathrm{PI} \text { ) }\end{array}$ & Sugano et al., 2001a and 2001b \\
\hline $\begin{array}{l}\text { Hydrophilic Filter Membrane PAMPA } \\
\text { Model (Aventis Model) }\end{array}$ & Egg lecithin, $1 \% \mathrm{wt} / \mathrm{vol}$ in dodecane & Zhu et al., 2002 \\
\hline $\begin{array}{l}\text { Permeability-Retention-Gradient-Sink } \\
\text { PAMPA Models (pION Models) }\end{array}$ & $2 \% \mathrm{wt} / \mathrm{vol}$ DOPC in dodecane & $\begin{array}{l}\text { Avdeef, } 2001 \text { and 2003; Avdeef } \\
\text { and Testa, } 2002\end{array}$ \\
\hline
\end{tabular}

PC, phosphatidyl choline; PE, phosphatidyl ethanolamine; PS, phosphadityl serine; PI, phosphatidylinositol; DOPC, dioleoylphosphatidylcholine Summarized form Avdeef, 2003 
lipids on silica particles in column work as the cell membrane, and the membrane permeability is predicted from the chromatographic affinity as represented by the IAM capacity factor (K $\mathrm{K}_{\mathrm{IAM}}$.).

$$
K_{I A M}=\left[\frac{t_{r}-t_{0}}{t_{0}}\right]
$$

where $t_{r}$ and $t_{0}$ are the retention times of drug and hold up time of the column, respectively. The IAM chromatography is a simple and potentially useful method for screening a large number of compounds. Reasonable correlation have been reported between IAM capacity factor, $\mathrm{K}_{\mathrm{IAM}}$ with $\log \mathrm{P}$ (Yang et al., 1996), intestinal drug absorption in mice (Ong et al., 1996; Yang et al., 1996) and rats (Pidgeon et al., 1995; Yang et al., 1996; Genty et al., 2001), human skin permeation (Yang et al., 1996) and Caco-2 cell permeation (Pidgeon et al., 1995; Ong et al., 1996). Recently, Yoon et al. (2004) reported an improved IAM chromatographic application by using a modified IAM capacity factor corrected by the power of the compound molecular weight $\left(\mathrm{K}_{\mathrm{IAM}} / \mathrm{MW}^{\mathrm{n}}\right)$. Nevertheless, the IAM capacity factor is governed mostly by the lipophilicity of the compound and, therefore, the IAM chromatographic assay have limitations in screening the permeability of compounds that are small and hydrophilic or transported by membrane transporters (Balimane et al., 2000).

\section{Cell-based systems}

Cell culture-based models are widely used to study the drug absorption potential and transporter or enzyme interactions. Currently available cell-based permeability models are summarized in Table III (Ganta et al., 2008; Ungell et al., 2003). Of these, Caco-2 and MDCK (Madin-Darby canine kidney) cell systems are most commonly used. These systems are well

Table III. Cell Culture Models Commonly Used for Permeability Assessment

\begin{tabular}{lll}
\hline \hline \multicolumn{1}{c}{ Cells } & \multicolumn{1}{c}{ Tissue Origin } & \multicolumn{1}{c}{ Comments } \\
\hline Caco-2 & $\begin{array}{l}\text { Human colon } \\
\text { adenocarcinoma }\end{array}$ & $\begin{array}{l}\text { Well known and widely } \\
\text { used; transporters and } \\
\text { enzymes are available }\end{array}$ \\
MDCK & Dog kidney epithelial cells & Low level of P-gp \\
LLC-PK1 & Pig kidney epithelial cells & Low level of transporters \\
HT-29 & Human colon & $\begin{array}{l}\text { Differentiated polarized } \\
\text { monolayer with mucus- } \\
\text { secreting and/or absorptive } \\
\text { cells }\end{array}$ \\
& & Showing CYP 3A5 activity \\
\hline
\end{tabular}

Summarized form Ganta et al., 2008 and Ungell et al., 2003 Figure legend standardized and can reflect various absorption mechanisms occurring in the gastro-intestinal tract such as transporter and enzyme interactions. These cell-based models have been widely utilized in the early stage drug development processes and the carrier-mediated permeability assessments (Taylor et al., 1997; Stevenson et al., 1999).

\section{Caco-2}

The Caco-2 cell system is one of the most popular and well characterized tools used in drug absorption screening (Hidalgo et al., 1989; Artursson, 1991; Artursson et al., 1994; Borchardt, 1995; Artursson et al., 1996; Rubas et al., 1996). The Caco-2 cells originate from a human colon adenocarcinoma (Fogh et al., 1977), thus they exhibit various intestinal cell properties (Ganta et al., 2008). The major advantages of Caco-2 cells over other simplified artificial systems are in the similarity with the actual intestinal tract. Caco- 2 cells have intercellular tight junctions and express numerous brush-border enzymes that can be found in the normal small intestine, including alkaline phosphatase, sucrase and amino peptidases (Pinto et al., 1983; Hauri et al., 1985; Chantret et al., 1988; Howell et al., 1992). In addition, cytochrome P450 isoenzymes (CYP450) and some phase II enzymes (e.g., glutathione-S-transferases, sulfotransferase and glucuronidase) have been identified (Baranczyk-Kuzma et al., 1991; Bjorge et al., 1991; Howell et al., 1992; Carrie're et al., 2001). Levels of the CYP expressions are, however, lower than those of the native intestinal cells (Pruesaritanont et al., 1996). Several influx and efflux transports have been characterized in the Caco-2 cell model (Hidalgo and Li, 1996). The group of OCT, OAT influx transports for glucose (Blais et al., 1987; Riley et al., 1991), amino acids (Hidalgo and Borchardt, 1990; Hu and Borchardt, 1992; Nicklin et al., 1992), dipeptides (Brandsch et al., 1994; Ganapathy et al., 1995; Thwaites et al., 1995), vitamins (Dix et al., 1990), and bile acids (Hidalgo and Borchardt, 1990; Wilson et al., 1990) as well as the efflux transports including MDR-1, Pglycoprotein (P-gp) (Hunter and Hirst, 1997), BCRP (Taipalensuu et al., 2001), and the multidrug resistance-related (associated) protein (MRPs) family (Kool et al., 1997; Stephens et al., 2001; Taipalensuu et al., 2001) have been identified in the Caco- 2 cells. Due to the similarity with the actual intestinal tract, Caco- 2 cells are considered the standard technique for predicting the oral absorption of drugs in humans (Camenisch et al., 1997; Hidalgo, 2001). Various studies have reported the correlation between the Caco-2 permeability and the fraction absorbed orally in humans (Artursson and Karlsson, 1991; Artursson et al., 1996; Yazdanian et al., 1997).

Caco-2 cells consist of a heterogeneous population of cells 
(Artursson, 1991), thus these intestinal cell properties such as morphology, tight junction, enzymes and transporters activity can be altered by different culture conditions (Hidalgo et al., 1989; Walter and Kissel, 1995; Hidalgo and Li, 1996; Delie and Rubas, 1997; Hidalgo, 2001). The permeability of mannitol (paracellular hydrophilic marker) shows a 100-fold difference depending on the source of Caco-2 cells; this variability may be due to the difference in culture conditions and the composition of cell populations (Walter and Kissel, 1995). The cell culture protocol and correlations need to be regulated and validated in each laboratory by measuring TEER, ${ }^{14} \mathrm{C}$-mannitol permeability and microscopic examination (Ungell and Karlsson, 2003).

The drug permeability may be expressed by the permeability coefficient $\left(\mathrm{P}_{\text {eff }}\right)$ through the cell monolayer as calculated by the following equation:

$$
p_{e f f}=\frac{V_{A}}{A\left(C_{D}-C_{A}\right)} \times \frac{d C_{A}}{d t}
$$

where $\mathrm{dC}_{\mathrm{A}} / \mathrm{dt}$ is the change of drug concentration in basolateral side over time, $\mathrm{A}$ is the membrane surface area, $\mathrm{V}_{\mathrm{A}}$ is the volume of solution in apical side, and $\mathrm{C}_{\mathrm{D}}$ and $\mathrm{C}_{\mathrm{A}}$ are the initial drug concentrations in basolateral and apical sides, respectively. Once the monolayer of Caco-2 membrane is prepared, the drug is added to the donor side, and the receiver side drug concentrations are monitored over time. Normally, the monolayers should be agitated during the experiment for more reproducible results as it may reduce the effect of aqueous boundary layers adjacent to the epithelial membrane that can results in an underestimation of the membrane permeability (Karlsson and Artursson, 1991).

There are limitations of the Caco-2 system that may lead to the mis-estimation of drug permeability. Due to the overexpression of tight intercellular junctions, the paracellular pathway may be limited, which may result in under-estimations in permeability for paracellularly transported compounds with MW $<150$ (Yee, 1997). Another limitation of this system is the under-expression of influx transporters such as peptide transporters (OCT, OAT). Thus, the substrates of these transporters including beta-lactam antibiotics and ACE inhibitors may be poorly permeated despite their high permeability property in vivo (Chong et al., 1997). The preparation of the monolayer membrane generally takes 21 days. However, the preparation time can be significantly reduced to less than 1-week by modifying both the coating material and the growth media (Chong et al., 1997). The recent trend of Caco-2 system is automation using a 24-well monolayer, LC/MS and robotics. A fully automated Caco-2 cell system can handle 500 to 2000 compounds per month. Despite some limitations, the Caco- 2 system is the most popular cell culture model in laboratory and industry (Ungell and Karlsson, 2003).

\section{Madin-Darby Canine Kidney (MDCK) cells}

Whereas Coco- 2 cells are originated from human colon adenocarcinoma, MDCK cells are derived from dog kidney cells. Owing to its different origin, expression levels of various transporters might be different from those of the human intestine. In the normal MDCK cell line, levels of efflux (e.g., P-gp) and influx (e.g., OCT) transporters are relatively low (Horio et al., 1989; Shu et al., 2001). Thus, this model may be sufficient for screening mainly passively transported drugs, while it may not be valid for screening actively transported drug. The major advantage of MDCK cells is the short culture time as the monolayer is formed within 3-7 days after starting the cell culture. An alternative cell model for MDCK is the MDR1-transfected LLC-PK1 cells (Adachi et al., 2001). However, the transfected cell line tends to form multilayers and not easily polarized (Hämmerle et al., 2000; Lentz et al., 2000).

\section{Tissue-based models}

The tissue-based models use the excised intestinal segment for measuring intestinal absorption. The advantage of the tissue-based model is to determine the membrane permeability using the real biological membrane and to easily screen different gastrointestinal segments for absorption potential. However, difficulty in maintaining the viability of the segments without blood supply is the main disadvantage of this model. Some examples of tissue-based models are described below.

\section{Isolated intestinal cells}

Isolated intestinal cell method was initially introduced in 1973 (Hopfer et al., 1973) and used extensively until recent years for characterizing intestinal drug transport (Murer \& Kinne, 1980; Sinko et al., 1995; Waclawski \& Sinko, 1996). The coarse membrane vesicles can be obtained by cell homogenates or intestinal scrapings and then purified by repeated precipitation-centrifugation procedures. The detailed procedures are introduced in a review paper by Hillgren et al (1995). The Isolated intestinal cells contain transporter proteins expressed on intestinal membrane, this allows for studying both passive and active transport pathways. However, one should keep in mind before using isolated intestinal cells that the prepared vesicles are not completely pure brush border cells but contain other types of cells and also transporter proteins and enzymes are prone to damage during the isolation process (Balimane et al., 2000). Compared with other tissue- 
based models, the advantage to this method is that 1) a small quantity of drug is needed to perform the study, 2) a sufficient quantity of isolated cells can be acquired using a small number of animals, and 3) isolated cells can be cryopreserved and used for a long duration (Balimane et al., 2000). This method is rather simple and suitable to use in early stage of drug discovery where the available quantity of compounds may be limited.

\section{Everted intestinal sacs}

Everted intestinal sacs are used to evaluate drug permeability by using real intestinal fragments. A $2-4 \mathrm{~cm}$ section of the intestine is isolated from anesthetized animal, washed in icecold buffer to clear the segment. One end of the intestinal fragment is tied and everted by pushing a glass rod through the closed end. Then, the sac is filled with buffer, tied off at the other end, and placed in a flask with oxygenated $\left(95 \% \mathrm{O}_{2} / 5 \%\right.$ $\mathrm{CO}_{2}$ ) buffer solution containing the compound. At the end of the experiment, the serosal fluid in the sac is collected and analyzed (Pento and Mousissian, 1988; Yamamoto et al., 1990). In this method, drug permeability is evaluated by using the real intestinal fragment, thus both the passive and active transports can be studied. Unlike isolated intestinal cells, the everted intestinal model can distinguish paracellular from transcellular pathways and can be used in the intestinal drug metabolism study (Bouer et al., 1999). The everted intestinal model has an additional advantage over other in vitro models because the absorption can be compared with different parts of the intestine while a small serosal volume is necessary.

A similar, everted intestinal ring method is also available. This method utilizes the everted intestinal ring instead of the everted intestinal sacs. This method has some drawbacks compared with everted intestinal sac method. Paracellular and transcellular pathways cannot be distinguished and the extraabsorption through exposed connective and muscle tissues at cutting side may result in overestimation of the permeability (Tukker, 2000).

\section{Diffusion cells}

Diffusion cells have been used to determine the drug transport in living cells. In 1951, Ussing and Zerahn first introduced the diffusion chamber so call Ussing cell (Ussing and Zerahn, 1951). In this method, appropriate size of the intestinal tissues is mounted between two chambers filled with oxygenated (95\% $\left.\mathrm{O}_{2} / 5 \% \mathrm{CO}_{2}\right)$ buffer including nutrients. The compound is added on donor chamber and the concentration in receptor chamber is measured as a function time. During the experiment, the potential difference between two cells is monitored and this potential is used to verify the viability of the mounted tissue during the experiment. The permeability of compound can be expressed as $\mathrm{P}_{\text {eff }}$ which is calculated by the similar equation used in the cell-based model.

$$
p_{\text {eff }}=\frac{d c}{d t} \times \frac{V}{A \times C}
$$

where $\mathrm{V}$ is the volume of the receiver chamber, $\mathrm{A}$ is the exposed tissue surface area, $\mathrm{C}$ is the initial drug concentration in the donor chamber, and $\mathrm{dc} / \mathrm{dt}$ is the change in drug concentration in the receiver over time. The diffusion cell technique can easily adopt different segments of the excised tissues, thus this method is ideal for studying the various regional absorption factors (Ungell, et al., 1998).

\section{In situ model}

The intestinal perfusion is the most commonly used in situ model. Various intestinal perfusion techniques have been introduced such as single pass perfusion (Komiya et al., 1980; Amidon et al., 1981), recirculating perfusion (Van Rees et al., 1974; Tsuji et al., 1978), oscillating perfusion (Schurgers and DeBlaey, 1984), and the closed loop method (Doluisio et al., 1969). Of these methods, the single pass perfusion is most popular and well characterized (Lennernäs, 2000). The single pass perfusion is performed under anesthetic conditions. In most cases, animals are fasted overnight prior to experimentation. An intestinal segment is usually washed out and the proximal and distal segments of the intestine are cannulated, and the perfusion starts at a flow rate of $0.2 \mathrm{ml} / \mathrm{min}$, a common perfusion rate in rats (Ho et al., 1983; Amidon et al., 1995; Fagerholm et al., 1996; Ganta et al., 2008).

In the single pass perfusion, net effective permeability $\left(\mathrm{P}_{\text {eff }}\right)$ is calculated by the following equation:

$$
p_{\text {eff }}=\frac{-Q_{\text {in }} \ln \left(C_{\text {out }} / C_{\text {in }}\right)}{2 \pi r L}
$$

where $\mathrm{C}_{\text {in }}$ and $\mathrm{C}_{\text {out }}$ are the inlet and outlet concentrations at steady state after perfusion start. $Q_{\text {in }}$ is the perfusion flow rate, and $2 \pi R L$ is the applied intestinal surface area. The major advantage associated with this method is the presence of an intact blood, nerve and lymphatic supply in the experimental animals (Balimane et al., 2000; Ganta et al., 2008). Thus, this method has been used for studying passive and active transports.

Despite such advantages, use of the single pass perfusion method is limited because the permeability $\left(\mathrm{P}_{\text {eff }}\right)$ is calculated by the difference between inlet and outlet concentrations from the luminal side. The decrease in concentration on luminal side 
does not, however, always represent the absorbed drug into the systemic circulation (Balimane et al., 2000). Another limitation is related to the amount of the test compound used. With this method, the steady-state condition for intestinal drug concentration should be achieved. To reach the steady state, a sufficient perfusion time and a large amount of compound are necessary. Yet, such a large amount of compound may not be easily obtainable in early stage of drug discovery (Balimane et al., 2000).

\section{In vivo method}

Loc-I-Gut method is a single-pass perfusion experiment used to assess the regional permeability in conscious species. Loc-I-gut technique can be used from dog (Lipka et al., 1998) to human (Knutson et al., 1989; Lennernäs et al., 1992). This technique needs a specialized instrument consisting of sterile polyvinyl tube with six inner channels and two inflatable latex balloons placed $10 \mathrm{~cm}$ distant (Knutson et al., 1989; Lennernäs et al., 1992). The tube is inserted into the gut and the positioning is achieved by use of the fluoroscopic technique. After positioning, the latex balloons are inflated to separate proximal to distal balloon regions, and a single pass perfusion is performed in the fasted state at a $2-3 \mathrm{~mL} / \mathrm{min}$ perfusion rate. The Loc-I-Gut method is a noninvasive method and thus it may be adapted in conscious animal and even in humans. This model can measure the regional drug absorption and drug dissolution at the absorption site. Another tool that can measure the in vivo regional drug absorption is the InteliSite capsule. The technique is rapid and totally noninvasive. In this technique, specially designed capsules release the drug by magnetic filed activation from outside of the body. The drug absorption can be measured by gamma scintigraphy (Pithavala et al., 1998).

\section{Conclusion}

Traditionally, the drug development strategy has focused primarily on the selection of appreciate target and in vitro and in vivo characterization of the pharmacological and toxicological profiles in the early stage developmental processes. However, a new paradigm for drug development has been shifted to screen the pharmacokinetic properties from the early stage of drug development. The oral absorption and membrane permeability are the key parameters of the pharmacokinetic properties. Thus, the need for more rapid, cost-effective, and highly predictive absorption screening methods has been increased. The drug absorption potential may be assessed by various in silico, in vitro, and in vivo methods. The lipophilicity, molecular weight, hydrogen bonding, $\mathrm{pKa}$, and solubility are the physiochemical parameters that are closely related to the intestinal permeability. These parameters may be relatively easily determined by the in silico methods. However, these methods are not sufficient to explain the real absorption conditions. The in vitro and in vivo absorption screening methods, on the other hand, require more tedious and time consuming labors and complicate experiments even though they are close to real absorption conditions and can provide more useful information. In this review, various in silico, in vitro, and in vivo methods for screening the drug permeability are introduced. Each method has its own advantages and disadvantages. The screening methods need to be selected with consideration of the sample number, time, labor, and the stage of drug development. Appropriate selection of the permeability screening methods at the right stage of the development process will help bring successful drug developmental outcomes.

\section{Acknowledgments}

This work was supported by a grant of the Korean Health Technology R\&D Project, Ministry for Health, Welfare \& Family Affairs (A092018) and the National Research Foundation of Korea (NRF) grant funded by the Korea government (MEST) (No. 2010-0022780).

\section{References}

Adachi, Y., Suzuki, H., Sugiyama, Y., 2001. Comparative studies on in vitro methods for evaluating in vivo function of MDR1 P-glycoprotein. Pharm. Res. 18, 1660-1668.

Amidon, A., Ho, N., French, A., Higuchi, W., 1981. Predicted absorption rates with simultaneous bulk fluid flow in the intestinal tract. J. Theor. Biol. 89, 195-210.

Amidon, G.L., Lennernäs, H., Shah, V.P., Crison, J., 1995. Theoretical considerations in the correlation of in vitro drug product dissolution and in vivo bioavailability: a basis for a biopharmaceutics drug classification. Pharm. Res. 12, 413420.

Artursson, P., 1991. Cell cultures as models for drug absorption across the intestinal mucosa. Crit. Rev. Ther. Drug Carrier Syst. 8, 305-330.

Artursson, P., Karlsson, J., 1991. Correlation between oral drug absorption in humans and apparent drug permeability coefficients in human intestinal epithelial (Caco-2) cells. Biochem. Biophys. Res. Commun. 175, 880-885.

Artursson, P., Lindmark, T., Davis, S.S., Illum, L., 1994. Effect of chitosan on the permeability of monolayers of intestinal epithelial cells (Caco-2). Pharm. Res. 11, 1358-1361.

Artursson, P., Palm, K., Luthman, K., 1996. Caco-2 monolayers in experimental and theoretical predictions of drug transport. 
Adv. Drug Deliv. Rev. 22, 67-84.

Avdeef, A., 2001. High-throughput measurements of solubility profiles, in Testa, B., van de Waterbeemd, H., Folkers, G., Guy, R., (eds.), Pharmacokinetic Optimization in Drug Research, Verlag Helvetica Chimica Acta, Zürich, and Wiley-VCH, Weinheim, pp. 305-326.

Avdeef, A., 2001a. Physicochemical Profiling (Solubility, Permeability, and Charge State). Curr. Topics Med. Chem. 1, 277351.

Avdeef A., 2003. Absorption and Drug Development: Solubility, Permeability, and Charge State. John Wiley \& Sons, Inc,. Hoboken, New Jersey , pp. 128-131.

Avdeef, A., 2003. High-throughput measurements of permeability profiles, in van de Waterbeemd, H., Lennernäs, H., Artursson, P. (eds.), Drug Bioavailability. Estimation of Solubility, Permeability, Absorption and Bioavailability Wiley-VCH, Weinheim, pp. 46-69

Avdeef, A., Strafford, M., Block, E., Balogh, M. P., Chambliss, W., Khan, I., 2001b. Drug absorption in vitro model: filter-immobilized artificial membranes. 2. Studies of the permeability properties of lactones in Piper methysticum Forst. Eur. J. Pharm. Sci. 14, 271-280.

Avdeef, A., Testa, B., 2002. Physicochemical profiling in drug research: A brief state-of-the-art of experimental techniques. Cell. Mol. Life Sci. 59, 1681-1689.

Balimane, P.V., Chong, S., Morrison, R.A., 2000. Current methodologies used for evaluation of intestinal permeability and absorption. J. Pharmacol. Toxicol. Methods 44, 301-312.

Baranczyk-Kuzma, A., Garren, J.A., Hidalgo, I.J., Borchardt, R.T., 1991. Substrate specificity and some properties of phenol sulphotransferase from human intestinal Caco-2 cells. Life Sci. 49, 1197-1206.

Benet, L.Z., Wu, C.Y., Hebert, M.F., Wacher, V.J., 1996. The importance of drug metabolism and antitransport processes: a paradigm shift in oral drug delivery. J. Control. Release 39, 139-143.

Bjorge, S., Hamelehle, K.L., Homa, R., Rose, S.E., Turluck, D.A., Wright, D.S., 1991. Evidence for glucuronide conjugation of pnitrophenol in the Caco-2 cell model. Pharm. Res. 8, 14411443.

Blais, A., Bissonnette, P., Berteloot, A., 1987. Common characteristics for $\mathrm{Na}+$-dependent sugar transport in Caco-2 cells and human fetal colon. J. Membr. Biol. 99, 113-125.

Bouër, R., Barthe, L., Philibert, C., Tournaire, C., Woodley, J., Houin, G., 1999. The roles of P-glycoprotein and intracellular metabolism in the intestinal absorption of methadone: in vitro studies using the rat everted intestinal sac. Fundam. Clin. Pharmacol. 13, 494-500.

Brandsch, M., Miyamoto, Y., Ganapathy, V., Leibach, F.H., 1994. Expression and protein C-dependent regulation of peptide/ $\mathrm{H}+$ co-transport system in the Caco-2 human colon carcinoma cell line. Biochem. J. 299, 253-260.

Broach, J.R., Thorner, J., 1996. High-throughput screening for drug discovery. Nature. 384, 14-16.
Burton, P.S., Conradi, R.A., Hilgers, A.R., Ho, N.F.H., 1993. Evidence for a polarized efflux system for peptides in the apical membrane of Caco-2 cells. Biochem. Biophys. Res. Commun. 190, 760-766.

Caldwell, G.W., Masucci, J.A., Evangelisto, M., White, R., 1998. Evaluation of the immobilized artificial membrane phosphatidylcholine. Drug discovery column for high-performance liquid chromatographic screening of drug-membrane interactions. J. Chromatogr. A. 800, 161-169.

Camenisch, G., Alsenz, J., Van de Waterbeemd, H., Folkers, G., 1998. Estimation of permeability by passive diffusion through Caco-2 cell monolayers using the drugs' lipophilicity and molecular weight. Eur. J. Pharm. Sci. 6, 313-319.

Camenisch, G., Folkers, G., Van de Waterbeemd, H., 1996. Review of theoretical passive drug absorption models: historical background, recent development and limitations. Pharm. Acta. Helv. 71, 309-327.

Camenisch, G., Folkers, G., Van de Waterbeemd, H., 1997. Comparison of passive drug transport through Caco-2 cells and artificial membranes. Int. J. Pharm. 147, 61-70.

Carr, K., Toner, P., 1984. Morphology of the intestinal mucosa. In: T. Csaky., (Ed.) Pharmacology of the Intestine. Springer-Verlag, New York, pp. 1-50.

Carrie're, V., Chambaz, J., Rousset, M., 2001. Intestinal responses to xenobiotics. Toxicol. In Vitro 15, 373-378.

Chantret, I., Barbat, A., Dussaulx, E., Brattain, M.G., Zweibaum, A., 1988. Epithelial polarity, villin expression, and enterocytic differentiation of cultured human colon carcinoma cells: a survey of twenty cell lines. Cancer Res. 48, 1936-1942.

Chong, S., Dando, S. A., Morrison, R.A., 1997. Evaluation of BIOCOAT2 intestinal epithelium differentiation environment (3-day cultured Caco-2 cells) as an absorption screening model with improved productivity. Pharm. Res. 14, 1835-1837.

Clark, D.E., 2001. Prediction of intestinal absorption and blood brain barrier penetration by computational methods. Combin. Chem. High Throughput Screen. 4, 477-496.

Clark, D.E., Pickett, S.D., 2000. Computational methods for the prediction of 'drug-likeness'. Drug Discov. Today 5, 49-58.

Comer, J.E.A., 2003. High-throughput Measurement of $\log$ D and pKa. In Van de Waterbeemd, H., Lennernäs, H., Artursson, P., (eds.) Drug Bioavailability: Estimation of Solubility, Permeability, Absorption and Bioavailability. WILEY-VCH Verlag GmbH \& Co. KGaA, Weinheim, pp. 25.

Conradi, R.A., Burton, P.S., Borchardt, R.T., 1996. Physico-chemical and biological factors that influence a drug's cellular permeability by passive diffusion. Methods Principles Med. Chem. 4, 233-252.

Cools, A.C., Janssen, L.H.M., 1983. Influence of sodium ion-pair formation on transport kinetics of warfarin through octanolimpregnated membranes. J. Pharm. Pharmacol. 35, 689-691.

Croop, J.M., Raymond, M., Haber, D., Devault, A., Arceci, R.J., Gros, P., Houseman, D., 1989. The three multidrug resistance $(\mathrm{mdr})$ genes are expressed in a tissue-specific manner in nonnal human tissues. Mol. Cell Biol. 9, 1346-1350. 
Dearden, J., 1990. Molecular structure and drug transport, in Hansch, C., Sammes, P.G., Taylor, J.B., (eds.), Comprehensive Medicinal Chemistry, Pergamon, Oxford, pp. 375-411.

Dearden, J.C., Ghafourian, T., 1999. Hydrogen Bonding Parameters for QSAR: Comparison of Indicator Variables, Hydrogen Bond Counts, Molecular Orbital and Other Parameters. J. Chem. Inf. Comput. Sci. 39, 231-235

Delie, F., Rubas, W.A., 1997. Human colonic cell line sharing similarities with enterocytes as a model to examine oral absorption: advantages and limitations of the Caco-2 model. Crit. Rev. Ther. Drug Carrier Syst. 14, 221-286.

DiMasi, J.A., Seibring, M.A., Lasagna, L., 1994. New drug development in the United States from 1963 to 1992. Clin. Pharmacol. Ther. 55, 609-622.

Dix, C.J., Hassan, I.F., Obray, H.Y., Shah, R., Wilson, G., 1990. The transport of vitamin B12 through polarized monolayers of Caco-2 cells. Gastroenterology. 98, 1272-1279.

Doluisio, J., Billups, N., Dittert, L., Sugita, E., Swintosky, J., 1969. Drug absorption. I. An in situ rat gut technique yielding realistic absorption rates. J. Pharm. Sci. 58, 1196-1200.

Fagerholm, U., Johansson, M., Lennernäs, H., 1996. Comparison between permeability coefficients in rats and human jejunum. Pharm. Res. 13, 1335-1341.

Faller, B., Wohnsland, F., 2001. Physicochemical parameters as tools in drug discovery and lead optimization. In Testa, B., van de Waterbeemd, H., Folkers, G., Guy, R., (eds.) Pharmacokinetic Optimization in Drug Research. Verlag Helvetica Chimica Acta. Zürich and Wiley-VCH, Weinheim, pp. 257274.

Fogh, J., Fogh, J.M., Orfeo, T., 1977. One hundred and twentyseven cultured human cell lines producing tumors in nude mice. J. Natl. Cancer Inst. 59, 221-225.

Ganapathy, M.E., Brandsch, M., Prasad, P.D., Ganapathy, V., Leibach, F.H., 1995. Differential recognition of b-lactam antibiotics by intestinal and renal peptide transporters, PEPT1 and PEPT2. J. Biol. Chem. 270, 25672-25677.

Ganta, S., Sharma, P., Garg, S., 2008. Permeability Assessment. In Gad, S.C., (eds.) Preclinical Development Handbook: ADME and Biopharmaceutical Properties. John Wiley and Sons Inc, New Jersey, USA, pp 227-248.

Genty, M., Gonzalez, G., Clere, C., Desangle-Gouty, V., Legendre, J.Y., 2001. Determination of the passive absorption through the rat intestine using chromatographic indices and molar volume. Eur. J. Pharm. Sci. 12, 223-229.

Gobas, F.A., Lahittette, J.M., Garofolo, G., Shiu, W., MacKay, D., 1988. A novel method for measuring membrane-water partition coefficients of hydrophobic organic chemicals:comparison with 1-octanol-water partitioning. J. Pharm. Sci. 77, 265272.

Hämmerle, S.P., Rothen-Rutishauser, B., Krämer, S.D., Gunthert, M., Wunderli-Allenspach, H., 2000. P-glycoprotein in cell cultures: a combined approach to study expression, localisation, and functionality in the confocal microscope. Eur. J. Pharm. Sci. 12, 69-77.
Hansch, C., Clayton, J.M., 1973. Lipophilic character and biological activity of drugs. II. The parabolic case. J. Pharm. Sci. $62,1-21$.

Hansch, C., Dunn, W.J., 1972. Linear relationships between lipocomes philic character and biological activity of drugs. J. Pharm. Sci. 61, 1-19.

Hauri, H.P., Sterchi, E.E., Bienz, D., Fransen, J.A.M., Marxer, A., 1985. Expression and intracellular transport of microvillus hydrolases in human intestinal epithelial cells. J. Cell Biol. 101, 838-851.

Hidalgo, I., Raub, T., Borchardt, R., 1989. Characterization of human colon carcinoma cell line (Caco-2) as a model system for intestinal epithelial permeability. Gastroenterology. 96, 736-749.

Hidalgo, I.J., 2001. Assessing the absorption of new pharmaceuticals. Curr. Top. Med. Chem. 1, 385-401.

Hidalgo, I.J., Borchardt, R.T., 1990. Transport of bile acids in a human intestinal epithelial cell line, Caco-2. Biochim. Biophys. Acta. 1035, 97-103.

Hidalgo, I.J., Li, J., 1996. Carrier-mediated transport and efflux mechanisms in Caco-2 cells. Adv. Drug Deliv. Rev. 22, 53-66.

Hidalgo, I.J., Raub, T.J., Borchardt, R.T., 1989. Characterization of the human colon carcinoma cell line (Caco-2) as a model for intestinal epithelial permeability. Gastroenterology. 96, 736749. 1205 Cell Cultures in Drug Discovery: An Industrial Perspective.

Hillgren, K.M., Kato, A., Borchardt, R.T., 1995. In vitro systems for studying intestinal drug absorption. Med. Res. Rev. 15, 83109.

Ho, N.F.H., Park, J.Y., Ni, P.F., Higuchi, W.I., 1983. Advancing quantitative and mechanistic approaches in interfacing gastrointestinal drug absorption studies in animals and humans. In Crouthamel, W., Sarapu, A.C., (eds.) Animal Models for Oral Drug Delivery in Man; In Situ and In vivo Approaches. American Pharmaceutical Association Washington, D.C., USA, pp 27-106.

Hopfer, U., Nelson, K., Perrotto, J., Isselbacher, K., 1973. Glucose transport in isolated brush border membrane from rat small intestine. J. Biol. Chem. 248, 25-32.

Horio, M., Chin, K.V., Currier, S.J., Goldenberg, S., Wiliams, C., Pasatan, I., Gottesman, M.M., Handler, J., 1989. Transepithelial transport of drugs by the multidrug transporter in cultured Madin-Darby canine kidney cell epithelia. J. Biol. Chem. 264, 14880-14884.

Howell, D., Kenny, A.J., Turner, J., 1992. A survey of membrane peptidases in two human colonic cell lines, Caco-2 and HT29. Biochem. J. 284, 595-601.

Hu, M., Borchardt, R.T., 1992. Transport of a large neutral amino acid in a human intestinal epithelial cell line (Caco-2): uptake and efflux of phenylalanine. Biochim. Biophys. Acta. 1135, 233-244.

Hunter, J., Hirst, B.H., 1997. Intestinal secretion of drugs: the role of P-glycoprotein and related drug efflux systems in limiting oral drug absorption. Adv. Drug Del. Rev. 25, 129-157. 
Hunter, J., Hirst, B.H., Simmons, N.L., 1993a. Drug absorption limited by p-glycoprotein-mediated secretory drug transport in human intestinal epithelial Caco-2 cell layers. Pharm. Res. 10, 743-749.

Hunter, J., Jepson, M.A., Tsuruo, T., Simmons, N.L., Hirst, B.H., 1993b. Functional expression of Pglycoprotein in apical membranes of human intestinal epithelial Caco-2 cells: kinetics of vinblastine secretion and interaction with modulators. J. Biol. Chem. 268, 14991-14997.

Kaitin K.I., DiMasi J.A., 2000. Measuring the pace of new drug development in the user fee era. Drug Inf. J. 34, 673-680.

Kaitin K.I., Healy E.M., 2000. The new drug approvals of 1996,1997, and 1998: drug development trends in the user fee era. Drug Inf. J. 34, 1-14.

Kansy, M., Fischer, H., Kratzat, K., Senner, F., Wagner, B., Parrilla, I., 2001. High-throughput artificial membrane permeability studies in early lead discovery and development. In Testa, B., van de Waterbeemd, H., Folkers, G., Guy, R., (eds.) Pharmacokinetic Optimization in Drug Research. Verlag Helvetica Chimica Acta. Zürich and Wiley-VCH, Weinheim, pp. 447464.

Kansy, M., Senner, F., Gubernator, K., 1998. Physicochemical high throughput screening: parallel artificial membrane permeation assay in the description of passive absorption processes. J. Med. Chem. 41, 1007-1010.

Kararli, T.T., 1989. Gastrointestinal absorption of drugs. Crit. Rev. Ther. Drug Carrier Syst. 6, 39-86.

Karlsson, J., Artursson, P., 1991. A method for the determination of cellular permeability coefficients and aqueous boundary layer thickness in monolayers of intestinal epithelial (Caco-2) cells grown in permeable filter chambers. Int. J. Pharm. 71, 51-64.

Kelder, J., Grootenhuis, P.D., Bayda, O.M., Delbressine, L.P., Ploemen, J.P., 1997. Polar molecular surface as a dominating determinant for oral absorption and brain penetration of dugs. Pharm. Res. 16, 1514-1519.

Kennedy, T., 1997. Managing the drug discovery/development interface. Drug Dis. Today. 2, 436-444.

Knutson, L., Odlind, B., Hallgren, R., 1989. A new technique for segmental jejunal perfusion in man. Am. J. Gastroenterol. 84, 1278-1284.

Komiya, I., Park, J., Yamani, A., Ho, N., Higuchi, W., 1980. Quantitative mechanistic studies in simultaneous fluid flow and intestinal absorption using steroids as model solutes. Int. J. Pharm. 4, 249-262.

Kool, M., de Haas, M., Scheffer, G.L., Scheper, R.J., Van Eijk, M.J.T., Juijn, J.A., Baas, F., Borst, P., 1997. Analysis of expression of cMoat (MRP2), MRP3, MRP4, and MRP5, homologues of the multidrug resistance-associated protein gene (MRP1), in human cancer cell lines. Cancer Res. 57, 3537-3547.

Krämer, S.D., 1999. Absorption prediction from physicochemical parameters. Pharm. Sci. Technolo. Today 2, 373-380.

Lennernäs, H., Ahrenstedt, O., Hallgren, R., Knutson, L., Ryde, M., Paalzow, L.K., 1992. Regional jejunal perfusion, a new in vivo approach to study oral drug absorption in man. Pharm. Res. 9, 1243-1251.

Lennernäs, H., 2000. Animal Perfusion Studies. In Dressman, J.B., Lennernäs, H., (eds.) Oral drug Absorption. Marcell Dekker, New York, pp. 73-98.

Lentz, K.A., Polli, J.W., Wring, S.A., Humphreys, J.E., Polli, J.E., 2000. Influence of passive permeability on apparent P-glycoprotein kinetics, Pharm. Res. 17, 1456-1460.

Leo, A., Hansch, C., Elkins, D., 1971. Partition coefficients and their uses. Chem. Rev. 71, 525-616.

Lipinski, C.A., 2002. Observation on current ADMET technology: no uniformity exists. Paper presented at the Proceedings of the Annual Meeting of the Society of Biomolecular Screening. The Hauge, The Netherlands.

Lipinski, C.A., Lombardo, F., Dominy, B.W., Feeney, P.J., 1997. Experimental and computational approaches to estimate solubility and permeability in drug discovery and development settings. Adv. Drug Deliv. Rev. 23, 3-25.

Madara, J., Trier, J., 1987. Functional morphology of the mucosa of the small intestine. In: L. Johnson (Ed.) Physiology of the gastrointestinal tract. Raven Press, New York, pp. 1209-1249.

Martin, Y.C., 1981. A practitioner's perspective of the role of quantitative structure-activity analysis in medicinal chemistry. J. Med. Chem. 24, 229-237.

Mueller, P., Rudin, D.O., Tien, H.T., Westcott, W.C., 1962. Reconstitution of cell membrane structure in vitro and its transformation into an excitable system. Nature. 194, 979-980.

Murer, H., Kinne, R., 1980. The use of isolated vesicles to study epithelial transport processes. J. Membr. Biol. 55, 81-95.

Nicklin, P.L., Irwin, W.J., Hassan, I.F., MacKay, M., 1992. Proline uptake by monolayers of human intestinal absorptive (Caco-2) cells in vitro. Biochim. Biophys. Acta. 1104, 283-292.

Ong, S., Liu, H., Pidgeon, C., 1996. Immobilized-artificial-membrane chromatography: measurements of membrane partition coefficient and predicting drug membrane permeability. J. Chromatogr. A. 728, 113-128.

Pento, I.T., Mousissian, G.K., 1988. Time-dependent deterioration of active transport in duodenal segments of rat intestine. J. Pharmacol. Methods 20, 9-14.

Pidgeon, C., Ong, S., Liu, H., Qiu, X., Pidgeon, M., Dantzig, A.H., Munroe, J., Hornback, W.J., Kasher, J.S., Glunz, L., Szczerba, T., 1995. IAM chromatography: an in vitro screen for predicting drug membrane permeability. J. Med. Chem. 38, 590594.

Pinto, M., Robin-Le'on, S., Appay, M.D., Kedinger, M., Triadou, N., Dussaulx, E., Lacroix, B., Simon-Assman, P., Haffen, K., Fogh, J., Zweibaum, A., 1983. Enterocyte-like differentiation and polarization of the human colon carcinoma cell line Caco2 in culture. Biol. Cell 47, 323-330.

Pruesaritanont, T., Gorham, L.M., Hochman, J.H., Tran, L.O., Vyas, K.P., 1996. Comparative studies of drugmetabolising enzymes in dog, monkey, and human small intestine, and in Caco-2 cells. Drug Metab. Dispos. 24, 634-642.

Raevsky, O.A., Fetisov, V., Trepalina, E., McFarland, J., Schaper, 
K.J., 2000. Quantitative Estimation of Drug Absorption in Humans for Passively Transported Compounds on the Basis of Their Physico-chemical Parameters. Quant. Struct. -Act. Relat. 19, 366-374

Raevsky, O.A., Grigor'ev, V.Y., Kireev, D.B., Zefirov, N.S., 1992. Complete thermodynamic description of H-bonding in the framework of multiplicative approach. Quantitative Structure Activity Relationships. 11, 49-63.

Raevsky, O.A., Schaper, K.J., 1998. Quantitative estimation of hydrogen bond contribution to permeability and absorption processes of some chemicals and drugs. Eur. J. Med. Chem. 33, 799-807

Riley, S.A., Warhurst, G., Crowe, P.T., Turnberg, L.A., 1991. Active hexose transport across cultured human Caco-2 cells: characterisation and influence of culture conditions. Biochim. Biophys. Acta. 1066, 175-182.

Rubas, W., Cromwell, M.E., Shahrokh, Z., Villagran, J., Nguyen, T.N., Wellton, M., Nguyen, T. H., Mrsny, R. J., 1996. Flux measurements across Caco-2 monolayers may predict transport in human large intestinal tissue. J. Pharm. Sci. 85, 165169

Sandstrom, R., Karlsson, A., Knutson, L., Lennemiis, H., 1998. Jejunal absorption and metabolism of $\mathrm{R} / \mathrm{S}$-verapamil in humans. Pharm. Res. 15, 856-862.

Schurgers, N., DeBlaey, C., 1984. Effect of pH, buffer concentration and buffer composition on the absorption of theophylline from the small intestine of the rat. Int. J. Pharm. 19, 283-295.

Shu, Y., Bello, C.L., Mangravite, L.M., Feng, B., Giacomini, K.M., 2001. Functional characteristics and steroid hormone-mediated regulation of an organic cation transporter in Madin-Darby Canine Kidney cells. J. Pharmacol. Exp. Ther. 299, 392-398.

Silverman, L., Campbell, R., Broach, J.R., 1998 New assay technologies for high-throughput screening. Curr. Opin. Chem. Biol. 2, 397-403.

Sinko, P. J., Hu, P., Waclawski, A. P., Patel, N. R., 1995. Oral absorption of anti-AIDS nucleoside analogues: 1. Intestinal transport of didanosine in rat and rabbit preparations. J. Pharm. Sci. 84, 959-965.

Stenberg, P., Luthman, K., Artursson, P., 2000. Virtual screening of intestinal drug permeability. J. Control. Release 65, 231-243.

Stephens, R.H., O’Neill, C.A., Warhurst, A., Carlson, G.L., Rowland, M., Warhurst, G., 2001. Kinetic profiling of P-glycoprotein-mediated drug efflux in rat and human intestinal epithelia. J. Pharmacol. Exp. Ther. 296, 584-591.

Stevenson, C.L., Augustijns, P.F., Hendren, R.W., 1999. Use of Caco- 2 cells and LC/MS/MS to screen a peptide combinatorial library for permeable structures. Int. J. Pharm. 177, 103-115.

Sugano, K., Hamada, H., Machida, M., Ushio, H., 2001a. High throughput prediction of oral absorption: Improvement of the composition of the lipid solution used in parallel artificial membrane permeability assay. J. Biomolec. Screen. 6, 189196.

Sugano, K., Hamada, H., Machida, M., Ushio, H., Saitoh, K.,
Terada, K., 2001b. Optimized conditions of biomimetic artificial membrane permeability assay. Int. J. Pharm. 228, 181188.

Taillardat-Bertschinger, A., Carrupt, P.A., Bardato, F., Testa, B., 2003. Immobilized artificial membrane HPLC in drug research. J. Med. Chem. 46, 655-665.

Taipalensuu, J., Törnblom, H., Lindberg, G., Einarsson, C., Sjöqvist, F., Melhus, H., Garberg, P., Sjöström, B., Lundgren, B., Artursson, P., 2001. Correlation of gene expression of ten efflux proteins of the ATP-binding cassette transporter family in normal human jejunum and in human intestinal epithelial Caco-2 cell monolayers. J. Pharmacol. Exp. Ther. 299, 164170. 1225 Cell Cultures in Drug Discovery: An Industrial Perspective.

Tayar, N.E., Testa, B., Carrupt, P.A.,1992. Polar intermolecular interactions encoded in partition coefficients: an indirect estimation of hydrogen bond parameters of polyfunctional solutes. J. Phys. Chem. 96, 1455-1459.

Taylor, E.W., Gibbons, J.A., Braeckman, R.A., 1997. Intestinal absorption screening of mixture from combinatorial libraries in the Caco-2 model. Pharm. Res. 14, 572- 577.

Testa, B., Carrupt, P.A., Gaillard, P, Billois, F., Weber, P., 1996. Lipophilicity in molecular modelling. Pharm. Res. 13, 335343.

Thiebaud, F., Tsuuo, T., Hamada, H., Gottesman, M.M., Pastan, I., Willingham, M.C., 1987. Cellular localization of the multidrug-resistance gene product P-glycoprotein in normal human tissues. Proc. Natl. Acad. Sci. USA 84, 7735-7738.

Thompson, M., Lennox, R.B., McClelland, R.A., 1982. Structure and electrochemical properties of microfiltration filter-lipid membrane systems. Anal. Chem. 54, 76-81.

Thwaites, D.T., McEwan, G.T.A., Hirst, B.H., Simmons, N.L., 1995. $\mathrm{H}^{+}$coupled a-methylaminoisobutyric acid transport in human intestinal Caco-2 cells. Biochim. Biophys. Acta. 1234, $111-118$.

Tsuji, A., Tamai, I., 1996. Carrier-mediated intestinal tansport of dugs. Phann. Res. 13, 963-977.

Tsuji, A., Miyamoto, E., Hoshimoto, N., Yamana, T., 1978. GI absorption of beta-lactam antibiotics II: deviation from $\mathrm{pH}-$ partition hypothesis in penicillin absorption through in situ and in vitro lipoidal barriers. J. Pharm. Sci. 67, 1705-1711.

Tukker, J.J., 2000. In Vitro Methods for the Assesment of Permeanility. In Dressman, J.B., Lennernäs, H., (eds.) Oral drug Absorption. Marcell Dekker, New York, pp. 51-72.

Ungell, A., Nylander, S., Bergstrand, S., Sjoberg, A., Lennernäs, H., 1998. Membrane transport of drugs in different regions of the intestinal tract of the rat. J. Pharm. Sci. 87, 360-366.

Ungell, A.L., Karlsson, J., 2003. Cell Cultures in Drug Discovery : An Industrial Perspective. In: Drug Bioavailability: Estimation of Solubility, Permeability, Absorption and Bioavailability. Van de Waterbeemd, H., Lennernäs, H., Artursson, P., WILEY-VCH Verlag GmbH \& Co. KGaA, Weinheim. pp. 90131.

Ussing, H.H., Zerahn, K., 1951. Active transport of sodium as the 
source of electric current in the short-circuited isolated frog skin. Acta. Physiol. Scand. 23, 110-127.

Van de Waterbeemd, H., Testa, B., 1987. The parametrization of Lipophilicity and other structural properties in drug design. Adv. Drug Res. 16, 85-225.

Van de Waterbeemd, H., 2000. Intestinal permeability: prediction from theory. Drugs Pharm. Sci. 106, 31-49.

Van de Waterbeemd, H., Camenisch, G., Folkers, G., Raevsky, O.A., 1996. Estimation of Caco-2 Cell Permeability using Calculated Molecular Descriptors. Quant. Struct. Act. Relat. 15, 480-490.

Van de Waterbeemd, H., Kansy, M., 1992. Hydrogen-bonding Capacity and Brain Penetration. Chimia. 46, 299-303.

Van de Waterbeemd, H., Smith, D.A., Beaumont, K., Walker, D.K., 2001. Property based design: optimization of drug absorption and pharmacokinetics. J. Med. Chem. 44, 1313-1333.

Van Rees, H., De Wolff, F., Noach, E., 1974. The influence of diphenylhydantoin on intestinal glucose absorption in the rat. Eur. J. Pharmacol. 28, 310-315.

Waclawski, A. P., Sinko, P. J., 1996. Oral absorption of antiacquired immune deficiency syndrome nucleoside analogues: 2. Carriermediated intestinal transport of stavudine in rat and rabbit preparations. J. Pharm. Sci. 85, 478-485.

Walter, E., Kissel, T., 1995. Heterogeneity in the human intestinal cell line Caco-2 leads to differences in transepithelial transport. Eur. J. Pharm. Sci. 3, 215-230.

Wils, P., Warnery, A., Phung-ba, V., Legrain, D., Scherman, D., 1994. High lipophilicity decreases drug transport across intestinal epithelial cells. J. Pharmacol. Exp. Ther. 269, 654-658.

Wilson, G., Hassan, I.F., Dix, C.J., Williamson, I., Shah, R.,
MacKay, M., Artursson, P., 1990. Transport and permeability properties of human Caco-2 cells: an in vitro model of the intestinal epithelial cell barrier. J. Control. Release 11, 25-40.

Wohnsland, F., Faller, B., 2001. High-throughput permeability $\mathrm{pH}$ profile and high throughput alkane/water $\log \mathrm{P}$ with artificial membranes. J. Med. Chem. 44, 923-930.

Yamamoto, A., Kawaratani, T., Kawashima, K., Hashida, M., Sezaki, H., 1990. Intestinal transport of sulfanilic acid in rats immunized with protein-sulfanilic acid conjugate. Pharrn. Res. 7, 767-771.

Yang, C.Y., Cai, S.J., Liu, H., Pidgeon, C., 1996. Immobilized artificial membranes screens for drug-membrane interactions. Adv. Drug. Deliv. Rev. 23, 229-256.

Yazdanian, M., Glynn, S.L., Wright, J.L., Hawi, H., 1997. Correlating partitioning and caco-2 cell permeability of structurally diverse small molecular weight compounds, Pharm. Res. 15, 1490-1494.

Yee, S., 1997. In vitro permeability across Caco-2 cells (colonic) can predict in vivo (small intestinal) absorption in man - Fact or myth? Pharm. Res. 14, 763-766.

Yoon, C.H., Shin, B.S., Chang, H.S., Kwon, L.S., Kim, H.Y., Yoo, S.E., Yoo, S.D., 2004. Rapid Screening of Drug Absorption Potential Using the Immobilized Artificial Membrane Phosphatidylcholine Column and Molar Volume. Chromatographia 60, 399-404.

Zhu, C., Jiang, L., Chen, T.M., Hwang, K.K., 2002. A comparative study of artificial membrane permeability assay for highthroughput profiling of drug absorption potential. Eur. J. Med. Chem. 37, 399-407. 